\title{
Intertextuality as the Strategy to Motivate Minangkabaunese Students to Do Learning Tasks
}

\author{
Yelfiza \\ English Education Study Program \\ STKIP PGRI Sumatera Barat \\ Padang, West Sumatera, Indonesia \\ yelfiza@stkip-pgri-sumbar.ac.id
}

\begin{abstract}
Since most students currently feel neglected to do learning task seriously and honestly, lecturers of English should find strategies which might contribute to the process of learning. One alternative strategy is using intertextuality when communicating learning tasks. Therefore, this research investigated types of intertextuality reflecting the lecturers' hegemony on the students of Teacher Training and Education College, Indonesian Republic Teachers' Association called STKIP PGRI to do learning and why the intertextuality could increase their motivation to do learning tasks. To answer the research questions, she applied qualitative research with Critical Discourse Analysis (CDA). Data were collected by recording lecturers' discourses, and analyzed by coding, categorizing, interpreting, and reporting. Findings show that five types of intertextualitywere used by lecturers, depicted their hegemony on students. They include a claim, warning, sarcasm, challenge, and a parody. Intertextuality can cause the students to be motivated to do learning tasks, mainly if it directly touches their soul. However, if it hurts their heart, it will not be useful to motivate the students. Thus, it is suggested for lecturers and teachers not to use intertextuality which may hurt the students' feeling.
\end{abstract}

Keywords—intertextuality, strategy, motivation, learning, tasks

\section{INTRODUCTION}

\section{A. Learning Process}

Doing learning task aslearning process,can charge the students' brain, since by following the process the students are engaged in doing conscious activities. Moreover, the conscious activities which are trained can become the students' habit so that it becomes subconscious. As the effect, getting involved in learning activities can become something like eating some food or something the students need when they learn.

Lecturers of English to Vygotskian need to provide learning situation since the experience with physical objects is necessary in cognitive growth. In addition, learning is constructed and language is the basis for cognitive development [1]. One branch of constructivist learning theories, social constructivism stresses on the importance of dialogue and of social interaction in the process of learning [2]. It can be done by asking them some questions and offering some tasks to do both during and after the learning process. On the other hand, becoming busy to make the students understand learning material through lecturing is impossible to charge their brain. They will be passive and learning process possibly does not happen. Finally, they will follow shortcutto succeed by cheating or copying other's work.

The fact that they previously did not follow the process maximally was found in some colleges in West Sumatera, yet they expected satisfactory result. Some students preferred learning without a burden of tasks. Listening and watching the lecturer's presentation and coming to class without any preparation were also preferable. In contrast, the class with full of task was disfavored. However, at the end of the semester, they expected a good result proved by their claim when they go bad mark.

The other fact was that lecturers sometimes did not have power to make students learn industriously. Meanwhile, power relations between lecturer and the students may influence the students to promote development [3]. It could be seen when they wrote their final project, paper or thesis. Some lecturers did not force the students to work maximally. Having consulted only several times, some students asked for the lecturer's approval of the papers or theses and in the same way, the lecturers directly approved them, even though they found many weaknesses in it. Moreover, they could not refuse when the students demanded that they be allowed to take a comprehensive test. In short, it is a dilemma for lecturers to apply Student-Centered Learning since many students have difficulty in understanding learning sources, mainly if they are written in English. Moreover, a large number of students in a class and limited sources may make the lecturer skepticism to apply the approach [4].

Viewing the phenomena, researcher was encouraged to do a research about communication strategy which might be essential to consider for making students learn seriously. Up to now, most students work for their extrinsic motivation; the lecturer still has meaningful and big contribution to the students' success. Therefore, their hegemony mainly in asking the students to learn may influence their students' behavior in learning.

One of the strategies interesting to study which becomes the basis of students' cognitive development is about the use of intertextuality. Therefore, there are two questions discussed thoroughly in this paper. First, what types of intertextuality did the lecturers use which reflected their hegemony when communicating learning task? Second, why could the 
intertextuality increase the students' motivation to do learning task? Finally, this research result is expected to have contribution to the improvement of the students' future task performances.

\section{B. Discourse Analysis and Minangkabaunese Culture}

Discourse used by participant is a depiction of their culture, since it is influenced by their culture as well as influencing their future culture. When one speaks or writes, he or she will use her knowledge and experiences linguistically and non linguistically. Linguistically, she or he will use lexical and grammatical variations to make audiences understand or influenced. In addition, she or he will also use nonlinguistic aspects to convince audience so that they can trust the speaker or writer. All linguistic and nonlinguistic aspects which are integrated when having interaction are studied in discourse.

Discourse is defined as different ways in which humans integrate language with non-language factors (the ways of thinking, acting, interacting, valuing, feeling, believing, and using symbols, tools, and object in the right place and at the right time). In addition, it is the language which is structured according to different patterns depending on domains of social life. So, there are various kinds of discourse as medical discourse, political discourse, economic discourse, classroom discourse, and it is contextually bound [5], [6], [7].

One of the discourse analyses is Critical discourse Analysis (CDA) which concerns the study with the relationship between language and power. In this approach, the scholars find the larger unit of text to the basic unit of communication [8]. There are various types of discourse analyses; Sinclair and Coulthard with descriptive system of analysis, Conversational Analysis which focuses on everyday life, Labov and Fanshel which focuses on heterogeneity of discourse, Potter and Wetherell which relates the discourse to psychology, and Critical Linguistics which marries a method of linguistic text analysis with a social theory of the functioning of language in political and ideological processes. CDA is a type of Critical Linguistics [10]. It concerns with the study of the relationship between language and power from the larger unit of text to the basic unit of communication [8].

Minangkabaunese people in general have some characteristics, namely they are very aware of politeness in associating with others as the following statements.

Nan tuo dihormati

those who are older must be respected

Nan ketek disayangi

those who are younger must be loved

Samoga dang bawo bakawan

those who are in the same age can be taken as friends Ibu jo bapak diutamokan mothers and fathers must be placed earlier [11].

Moreover, in interacting with their society, they have important principles regarding to social life. It is democratic which is called "demokrasi Tuah sakato" described in their philosophy "kalau lurusnya menahan tilik, kalau adilnya menahan banding" (it is exactly right and wise). In addition, it is measurable called "ukua jo jangko" which contains some social practices when associating with the people, "andak luruih rantangkan tali (speaking appropriately, politely, and peacefully), andak tinggi naiakkan budi (to be a person with high status in the society, one should make her or his attitude better), andak aluih baso jo basi (one must consider what to say which can please others and speak politely), andak mulia tapati janji (people should fulfill their promise. Whatever obstacles they meet, they will not break promise)[12].

In learning process, lecturer has some functions as motivator and facilitator. To meet their functions, they will take responsibility on communication practice and the way they communicate to the students can determine whether they have done their function appropriately or not. Moreover, it may also affect the students' behavior in learning. They may follow the lecturers' instruction or just take it easy.

Learning process at university may contain some kinds of learning tasks. They students should think and do the tasks more actively. Listening to the lecturers' instruction, the students decide what to do, how to do, and why to do. The students may do such task, but some students choose a deviant way to accomplish it and do not think of the deviancy. Even, they think they have done something properly and do not accept if they get mad mark. Furthermore, knowing the purpose of doing the task is recommended before doing it to lead the students' action during the task.

Principle of Minangkabaunese people in doing a task is fundamentally important to socialize and introduce to the students. Naturally, Minangkabaunese students can do learning task maximally and honestly if they realize their potential and are trained to be industrious since their childhood. Their potential is depicted in "pepatah" or proverb "Duduak marauik ranjau, Tagak maninjau jarak", (sitting while whittling a booby trap, standing while viewing the space, meaning that they are diligent reflected by how they spend their time with useful activities or work continually [13]. It is the lecturers' task to make them know and qualify their potential in task performance. To implement it, training is very urgent since it can make them accustomed to a hard work. Moreover, feeling dislike having a burden of task must be replaced to the need of the work.

\section{Intertextuality as Motivating Strategy}

The idea of intertextuality is inspired from Baktinian perspective on dialogicality. Adapting the concept of dialogicality, Kristevastates that any text is constructed of a mosaic of quotations, the absorption, and transformation of another [14]. One of the strategies of making the students understand the information given orally is by using intertextuality. Similar with the situation in teaching writing, when communicating learning task, the lecturer may use the discourse containing complicated information, so she or he needs intertextuality to make them clear. In short, lecturer can reduce the students' difficulties and increase their understanding by using intertextuality [14]. 
In defining intertextualityAllen states that every text has its meaning in relation to other texts and the various permutations of this relationality. It can be the relation between signs and texts and the cultural text, the relation between a text and the literary system, or the transformative relation between one text and another text [15]. Furthermore, speakers always build something new by infusing it with their recollection of textual fragments from previous instances of speech [16]. Finally, intertextualityis defined as the way that texts refer to or incorporate aspects of other texts within them [17].

Intertextuality used by lecturer can be various depending on the need to support the text. It can include explicit references, implicit references, embedding by means of paraphrase, summary, and embedding in a text by means of direct quotes [18]. Intertextuality is also categorized into parodies, retelling, sampling, direct reference or quotation, and allusion [17].

In learning, the use of intertextuality must be proposed to get a certain purpose. In writing, for example, it can be to increase the students' effort to work [19]. They can do their best in doing the task, and when needed, they will revise it till they become sure that the task is valuable. They may not be bored and hurt hearted when asked to revise their task again and again. They think that it is important for their development of knowledge. In similar way with writing, in communicating learning task, a lecturer can extend the students' response to enhance their understanding of how she or he creates the discourse and interconnects the nature of speaking and listening.

In addition, the Intertextuality can be also used to solve the students' problems of learning attitudes. If the students have negative image on a certain task or on the lecturer, they must be involved in emotional and sensational activities in the classroom by using intertextuality, as parody. Thus, the lecturer needs to understand immediate individual experience, a social reality to extend and modify reality of senses [20]. Those who have been accustomed to perceiving other's help and never been struggling in their lives, possibly find difficulties in changing their character.

In the effort of changing their attitude, the lecturer needs to be able to motivate them. To be motivated, the students need four important factors of initial motivation: (1) probability of success, (2) anxiety, (3) interest, and (4) challenge [21]. The factors should be taken into account in selecting intertextuality.

The situation in which the students are not motivated to do learning tasks is a big challenge for a lecturer. It needs the lecturer's consideration of how they can feel that the task is urgent for their lives. Thus, it is required for a lecturer to help students regulate their motivation to do the task. Wolters identifies eight key strategic ways to encourage students regulate their motivation to do their learning tasks. They are 1) self-consequating: identifying and administrating selfprovided extrinsic rewards or punishments, 2) goal-oriented self-talk "talking themselves into increased performance", 3) interest enhancement, as by turning a task into a game, 4) environmental structuring: decreasing the possibility of off- task behavior by reducing the probability of encountering distractions or reducing the intensity of distractions, 5) selfhandicapping: manufacturing obstructions before and during the task to make the task more difficult, so that the students create win-win solution, if they fail, they can use the obstacles as a mitigating circumstances and if they succeed they can put them in a particular good light, 6) attribution control: it is manipulated after the task has been completed, 7) efficacy management: as a) proximal goal setting-breaking complex tasks into simpler and more easily completed segments, b) defensive pessimism-highlighting one's level of unpreparedness or lack of ability in order to increase anxiety, and c) efficacy self-talk, such as "You can do it", and 8) emotion regulation, by reducing negative affective response or using wishful thinking [22].

Moreover, Kristiva'sconcern for respecting the subject as a producer of meaning, pathological or not, is at the root of her emphasis on the ethics of psychoanalysis called heretical ethics, or the Herethic known as an ethics of love [23]. One important lesson that can be found from Kristeva's work is that the problem of unmotivated students is one of the educational problems needed to solve. Lecturer's text reflecting ethics of love is something which may affect their emotion. If the text uttered to them is not to impress them, but show respect and awareness, they can increase their motivation to do learning task.

\section{Learning Task at University}

Learning situation at university is different from that in lower levels of education. Student-centered learning is more applicable at university since the students can learn independently. Therefore, lecturer just facilitates the students to learn by providing some topics to discuss and monitoring the discussion process. In contrast, at elementary to high school, the students' dependence is very limited. They tend to wait for the teachers' instruction before doing something. Moreover, in the process, they need meaningful help from the teacher to do a certain task. In other words, learning has been characterized by the acquisition of knowledge, the knowledge gained through study, teaching instruction, experience, the process in which behavior is changed, shaped, and controlled, the change is as the result of experience or practice, and individual process of constructing understanding based on experience from various sources [2].

The philosophy of learning, constructivism suggests that learning takes place when new information is built into and added on to an individual's current structure of knowledge, understanding and skills. One branch of constructivist learning theories is known as social constructivism which stresses on the importance of dialogue and of social interaction in the process of learning. In addition, learning is a situated process meaning so that it takes place in a context. Finally, learning is a metacognitive process which is concerned with thinking about thinking [2]. This philosophy must be suitable with learning situation at university level. The students at university level must do deep leaning to construct their cognition. Unless they construct 
metacognition, they cannot compete with other people and cannot give contribution to other people.

Moreover, learning requires a serious effort of the learner. The learner must be active physically and mentally. To do this they must be engaged in the activity of learning. The mental activity includes exploration, through which the process of providing an overview of what is covered in the information under consideration. The next one is transformation meaning reproducing notes and other ideas from a text to be in a format needed by the learners. The following stage of mental activity is presentation by which the information is presented as an end product. Finally, the reflection is the time when the ideas can be revisited and reviewed. They can be fully understood and assimilated [2].

Based on the role of the participants, the tasks can be categorized into some typologies; required exchange tasks, optional exchange tasks, convergent tasks, and divergent tasks. Required exchange tasks are the tasks in which information has to be passed from one speaker to the other in order for the task completed. Optional exchange tasks are the task in which information can be passed from one to the other, although it is not required and the actual information to be exchange may not be provided by task. Then, convergent tasks are the tasks in which all speakers are working to a joint agreed outcome. Finally, divergent tasks are the tasks in which speakers can come to different conclusions or outcome [24].

Furthermore, there are four ways that make adult learners different from child learners [25]. They are self-concept, experience, a readiness to learn, and an orientation to learning. Specifically, regarding to the approach, Johnson in his theory about task oriented teaching reveals that methodologies should not only be based on linguistic insights as to the nature "knowledge of a language", but also psycholinguistics insights as to the processes involved in its use [24]. Therefore, the fluency in communication process can only be developed within task oriented teaching. Taskoriented teaching or task-based learning is appropriately applied at university, because the students were prepared to be agents of their own learning.

\section{E. Lecturers' Hegemony}

Hegemony and power are two related terms because hegemony is the domination of power in social relation. It is social condition in which all aspects of social reality are dominated by or supportive of a single class [26] [10].Moreover, Gramsci presented hegemony as the means whereby social forces, manifest throughout not only civil society but also what is conceived of as political society [26]. The term hegemony is also used in education as 'the way hegemonic epistemologies; 'how particular kinds of knowledge and "science" have been able to acquire a dominant position, while at the same time too many others outside the Western realm of rationality have been silenced' [27].
Moreover, power relations may impact the recipient in two opposing ways: they can influence the recipient to promote development, but at the same time, they may affect the recipient to impede development. They have some features, namely multi-directional, structured, context specific and strategic [3]. It is also argued that hegemony and humans hasnever lived in post-hegemonic times [28]. In addition, social order was never secured through ideology, but through habit and affect, social change is achieved. In learning, forming and changing habit is one of the purposes instead of other purposes; increasing knowledge as well as improving the students' skill.

As learning proceeds, a lecturer may have dilemma in applying dialogic student-centered methodologies and the authority vested in their role. The lecturer-student 'exchange' illustrates the tension between democratic forms of education and the latent tendency to lecturer hierarchy. For example, the lecturer draws attention to her potential to exercise power. Her or his 'silence' may emerge for collaborative work, such as the when students change their role from listener, observer, and note-taker to active problem-solver, contributor, and discussant [27]. Fortunately, by watching and listening to intertextuality which can reflect the lecturer's competence, the students can trust her or him. Consequently, they attend and follow the lecturer's idea in the discourse. Firstly they may feel difficult to do it, but soon after their habit is formed, whatever ideas are suggested in the discourse, they can follow them.

\section{METHOD}

This research is qualitative research with ethnographic approach and with content analysis. It was done at STKIP PGRI Sumatera Barat with English lecturers were selected as participant purposively. Sampling process was done twice, before and after collecting the data. From six lecturers initially observed, only three of them were taken as participants since they produced the discourse relevant to the topic of this research.

Instrumentation of this research was observation, by which the researcher observed the participant when they taught and she recorded their discourse. Thus, the researcher used video to record their utterances. The observation was done to six lecturers who taught Research in Language teaching, Classroom management, Speech, Paper and Thesis Writing, and Translation. But the data were found from three of them, namely, from those who taught Classroom anagement, Research in language Teaching, and Speech. Finally the data were analyzed textually and contextually by organizing them into some types of intertextuality, exploring and coding, using the code to describe the data, representing, reporting, and interpreting sociologically and psychologically [10], [29], [30], [31].

\section{FINDING AND DISCUSSION}

As this research wants to find out the answers of the questions about "What types of intertextuality the lecturers 
used which reflected their hegemony when communicating learning task and why the intertextuality can increase the students' motivation to do learning task," the researcher follows some procedures as stated under methods of research. Finally, this research result is expected to have contribution to the improvement of the students' future task performances.

\section{Excerpt 1 \\ ${ }^{1}$ And the last one, make the research question, through your research question we will conduct the title of your research. \\ ${ }^{2}$ Jadi bagi yang tidak ada problem besok, yang tidak ada mengidentifikasi research question, tidak saya izinkan untuk membuat judul... \\ So, if you do not have any problems tomorrow, not identify research questions, I will not allow you to submit a proposal title (quoted from text 1)}

The above discourse occurs in teaching Research. After listing some tasks given to the students, she used intertextuality which was told them firmly (see utterance 2). It was uttered to the students since the lecturer were worried if they did not do the task. The lecturer could do it because she had power to tell it since she was assigned to be the evaluation team of the research title. The students certainly are worried if they do not have possibility to submit their title. As the effect, they should do their task. However, the effect of such warning cannot remain long; only as long as the lecturer places the position. On the other hand, in positive sense, warning by telling the advantages of doing the task, may be more impressive for the students.

Moreover, using the intertextuality 'threat,' she shows her power to force the students, so the students felt fear if they did not follow the lecturer's command. This way may make the students work as commanded, but just perform limited activities to meet the lecturer' requirement. It will be different if the lectures' power was based on her expertise [32] since the students were eager to be competent. Their eagerness will enhance them to work maximally and if they cannot do or not understand it, they will seek information through internet or by discussing it with the lecturer. Such warning is applicable to prevent the students from neglecting the task

Another kind of warning is used due to the adaptive nature of memory. The feedback training procedure may have application potentials for people suffering from the severe false memory symptoms due to ageing and other aspects to modify their remembering behaviors [33]. It can be use despecially when the students hate learning task because they have got bitter experience with the task or they become tramatic with the task. Thus, warning can be used to make them have responsibility of their work.

Warning in the data above was used to prevent the students' previous habit, for example, they were not aware of learning task or frequently did not do the task. The utterance was not expressed if there was no background context regarding to the students' habit. The text shows the lecturer's power on her text in making the students do learning task.
Sociologically, the text shows the lecturer' power to the students by using such warning. Yet, it is not suitable for Minangkabaunese character 'feeling aware of politeness in associating with other people [13]. In contrast, win-win solution is more preferable, for example by telling that those who submit the title will be served firstly when submitting the title. Positive mental readiness may be much more helpful than the negative one. The pattern can be formulated below.

$\mathbf{W n}+\mathbf{H b A}=\mathbf{H M}>\langle\mathrm{Wn}+\mathrm{HbP}=\mathbf{L M}$

Figure 1. Pattern of warning

From the above pattern, warning can be classified into two forms; hegemonic based power and hegemonic based authority. Warning used with hegemonic based authority (Wn $+\mathrm{HbA})$ is much more effective in motivating (HM) the student to do learning task since they can do it more seriously and can stay working longer. On the other hand, warning used with hegemonic based power $(\mathrm{Wn}+\mathrm{HbP})$ can influence the students to work under the lecturer's command and if the lecturer does not monitor the work, the influence may be reduced or the students have low motivation (LM). Moreover, monitoring enhancement occurred in both phases (retrieving and encoding) and that the two sources of enhancement interacted with each other [34].

Excerpt 2

3 ... Itu dia sudah terjawab.

It is the answer

${ }^{4}$ Any question?

${ }^{5}$ Kalau tidak ada sesuai dengan janji kita tampil

kedepan one by one.

If there is no more question, perform your speech in

front one by one(quoted from text 2)

In learning process, claiming the students to do learning task is very natural, especially if the lecturer has facilitated the students to learn (see utterance 5). However, if the lecturer does not facilitate the students to learn before claiming them to work, it will be dysfunctional. The students may do the task without considering their comprehension and the quality of the task. As the result, their work is just to waste the time but not useful for their learning progress.

In the above discourse, the lecturer claimed the students to perform a free speech after providing the time for them to ask anything related to the topic. Unfortunately, before claiming them, the specific skill to train was not clear. It is not coherent with what Cavell asks that it should be done to pursue criteria underlying a way to educate the students [35].

Having claimed the students to answer the lecturer's question or do a certain task, lecturer can get contextual information from their response. Moreover, Thomas, Bulevich, \& Dubois then, reveal that when the students have feedback about the correctness of their answers ( $F c)$, their level of knowing judgments and their accuracy also increase. Then, it can be described as the following pattern [34]. 


\section{$\mathrm{Cm}+\mathrm{CSd}+\mathrm{Fc}=\mathrm{HM}><\mathrm{Cm}+\mathrm{USd})-\mathrm{Fc}=\mathrm{LM}$}

Figure 2. Pattern of claiming

The above pattern shows that Claiming $(\mathrm{Cm})$ is important activity done in relation to learning task. Using intertextuality to claim the task shows the lecturer's discourse consistency. If she or he always claims the consensus made with a clear standard (CSd), he or she may avoid the students' unawareness or the students can be more motivated (HM), but not vice versa. However, claiming learning task without a clear standard (USd) may be less influential to make the students work maximally. Thus, the pattern of claiming can be formulated as the following formula.

\section{Excerpt 3}

${ }^{6}$ Kalau tidak ada sesuai dengan janji kita tampil kedepan one by one.

If no more question, as what we promise, perform your speech infront.

${ }^{7}$ Pasti ada pertanyaan sekali kalau disuruh tampil... You must have a question if asked to perform a speech(quoted from text 2)

Since no more students asked any questions related to the topic discussed on that meeting, the lecturer said 'Kalau tidak ada sesuai dengan janji kita tampil kedepan one by one.' However, the command was soon followed by another statement, 'Pasti ada pertanyaan sekali kalau disuruh tampil...' Since the statement was uttered in this situation, it may be interpreted that the lecturer knew the students' habit when asked to perform. They asked some questions just to avoid performing a speech. In fact, no one refused to perform their speech in front of the class.

Though sarcasm $(\mathrm{Sc})$ is one of the ways that enable a lecturer to make the students do the task, it is considerably impolite and un-enjoyable since the lecturer has negative thinking (NTh) about her students. It also can make a gap between the lecturer and the students. Furthermore, it is prone to use when someone is in anger which attempts to change or to influence students' behavior, but it cannot motivate them to study or to be smarter (UMt) [36]. Sarcasm may involve humor and figurative speech $(\mathrm{Hm})$. Using it may reduce the threat which may maximize the information processing and considering of a large number of solution to their problem and then may influence their motivation (Mt). Conversely, what is suggested to do to avoid the students' reluctance is telling them their probability of success (TPS), for example, 'It is easy, I am sure you can do it well' [22]. In addition, problems that involve low levels of ambiguity and that can be handled through routine procedures may benefit from the narrow focus of attention (NF) ignited by the sense of threat [36]. The pattern can be described below.

$$
\mathrm{Sc}+\mathrm{NTh}=\mathrm{UMt}>\langle\mathrm{Sc}(\mathrm{Hm})+\mathrm{TPS}+\mathrm{NF}=\mathrm{Mt}
$$

Figure 3. Pattern of Sarcasm
From the data analysis above, it can be argued that sarcasm is not motivating since it can threat the students. On the other hand, if it is used humorously, the threat can be reduced. Using intertextuality may be useful to tell their probability of success so that they become confident. Moreover, by making the topic narrow, the lecturer can reduce the students' threat. Since it was produced soon after the task was announced, it reflected the lecturer's negative presupposition toward the students' habit or negative judgment. It is opposite with character of Minanngkabau which is excessive [37].

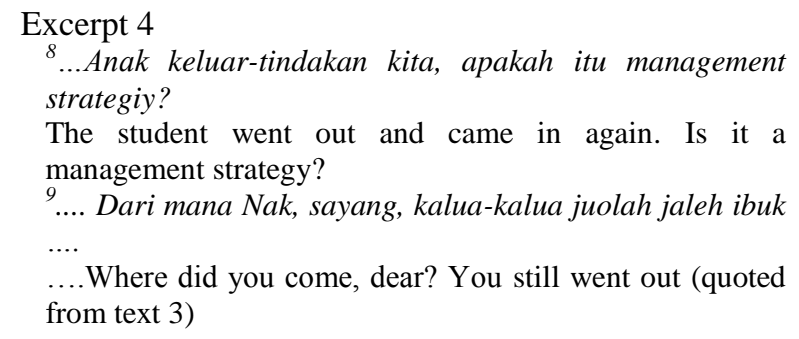

The discourse was used when a lecturer transmitted the concept of classroom management to the students through classroom discussion. She used questioning techniques and the students had various answers for one question. Before coming to the concept she used a parody (see utterance 9).

Parody (Pr) is a humorous activity that a lecturer may use when communicating learning task. It may make the classroom situation enjoyable and alive if the lecturer can use it meaningfully (UM) and as the effect the students may catch the information easily (CI). Sometimes learning without humor $(\mathrm{LwH})$ can cause the students bored easily $(\mathrm{Br})$. As the effect the students cannot catch the information completely (CI). Parody is categorized into two kinds; ideological parody (or satire) is directed against political opponents; generic parody involves playing with linguistic norms and generic conventions Furthermore, ironic expressions can be interpreted on the basis of their linguistic properties, hyperbolic expressions, illogicalities, and inconsistencies [38]. It is summarized as the following pattern.

$$
\operatorname{Pr}(\mathrm{UM})=\mathrm{CI}>\langle\mathrm{LwH}(\mathrm{Br})=-\mathrm{CI}
$$

Figure 4. Pattern of Parody

In the data above, the lecturer used hyperbolic expression to attract the students' attention to the topic. Since the utterance is illogical and inconsistent to the teacher's activities, the students may be awakened and become attracted (the situation is meaningful). Moreover, parody and humorous utterances used by lecturer can disguise and enable the students to do serious identity work by providing a resource for exercising discursive power [39].It is contrasted with the previous sarcasm which is motivated by anger. It is described below.

Excerpt 5

${ }_{10}$...Apa pertanyaan yang mungkin muncul dengan situasi yang tadi? 


\begin{abstract}
What question may occur in the previous situation? ${ }^{11}$ Cahyani tiba-tiba keluar tanpa minta permisi misalnya, kemudian dia masuk lagi.

Cahyani went out suddenly without having permission from the lecturer, for instance, then she entered again....

(quoted from text 3)
\end{abstract}

The discourse occurred since one of the students got permission from the lecturer to go out during the classroom activities and all students can see the situation (see utterance 11). It is the real situation that used as illustration (Ir). It is a model of classroom management that can be applied to explain a concept. It is coherent with Bandura's theory of modeling(Md) [1].The lecturer used real situation (RS) in inspiring the students to understand the text. Through this way, the students can see directly the situation in which the text is used. By relating the text and the illustration, the lecturer can bring the abstract message into the concrete one to enable them to catch the meaning. Moreover, the students' experience of success can increase their motivation [40]. In short, the pattern can be seen below.

$$
\text { Ir }(\text { Md + RS })=\text { MCx }
$$

Figure 5. Pattern of Illustration

Conveying a concept is much more boring because it is abstract. Thus, using illustration is one of the alternatives a lecturer can use to minimize the complexity ( $\mathrm{MCx}$ ) of a task and it is one factor of motivation [21].The illustration used by the lecturer in the above discourse was taken from the real situation when one of the students asked for permission to go out while the learning process. She used the situation and related it to a teacher's activity in the classroom, especially classroom management activity. She encouraged the students to tell their opinion if they find this situation in their future class. Then, the pattern is described below.

\section{CONCLUSION AND RECOMMENDATION}

\section{A. Conclusions}

Findings prove that five types of intertextuality can ignite students' motivation to do learning task, but the level of influence can be different. It was also found that a variety of influences when intertextuality is used in communicating learning task were caused by some reasons sociologically and psychologically.

The first type of intertextuality is 'Warning' which is always positive. When a lecturer uses it based on hegemonic authority, the students will be more motivated.

The second intertextuality is 'Claiming' which can be meaningful if it is done based on a clear standard. Following the standard, the students will be more careful in doing the task, and consequently the result of their task can be better. In claiming, the lecturer dominates the discourse, meanwhile the students just listen and obey what the lecturer asks. The third intertextuality is 'Sarcasm' which is related to anger. It is not suggested to use since Minangkabau people are very sensitive with this type of text.

The next intertextuality is parody which shows balance in the lecturer-students relationship. Eventhough it is produced by the lecturer, but domination is not directly seen from the intertextuality. It is slightly simple communication and can be used just for fun. But in teaching, none of the classroom activity runs without any purposes. When the students feel fun with what the lecturer says, they may be influenced easily. Instead of making the situation relaxed, it can be used to give information indirectly. Fundamentally, Minangkabau people are more impressed with indirect language since it is considered more polite.

The other intertextuality is 'Illustration' or a more detailed real situation used to show the meaning of the main text. This intertextuality can be used naturally by an experienced lecturer and the use depicts his or her mastery. Knowing that the lecturer fully masters a topic, can raise their trust to the lecturer which then, leads them to become ready to be influenced or dominated. Finally, good ideology but not socialized and trained in their social life, cannot change people's habit and affect and their habit and affect can change the social order.

\section{B. Recommendation}

Lecturers' hegemony must be based on their expertise, so they are recommended to acquire the task completely before commanding their students to do the task. In addition, they are required to motivate students to do learning task since doing the task is the central activity at university level. To do it, they need to learn and use intertextuality. However, before using the intertextuality, they should recognize the students' difficulty and their habit in learning in order that they can adjust which intertextuality is useful for the students and how to use it effectively. Finally, as the strategy to motivate the students, the intertextuality should be integrative to other intertextuality (s) and with other strategies.

\section{Acknowledgment}

Author greatly appreciates KemenristekDikti for the funding of this research in order that she can finish this project completely. She is also very grateful to Kopertis Wilayah $X$ for facilitating her to get the funding. Appreciation is also due to all leaders atSTKIP PGRI Sumatera Barat who had supported her in accomplishing this research project, which then leading her to produce this article.

\section{References}

[1] K. Krapp, Psychologists and their Theories for Students. New York: Thomson Gale. New York : Thomson Gale, 2005.

[2] A. Pritchard,Studying and Learning at University; Vital skills for Success in Your degree. Los Angeles: Sage, 2008.

[3] M. Maeda, "Power relations among actors in development cooperation: Patterns, concepts and approaches in a Japanese-assisted teacher training project in Cambodia.Maeda," International Journal of Educational Development, vol.28, 2008, pp.359-360 doi: 10.1016j.ifedudev. 
[4] P.K. Rangachari, "Putting Students in Charge: A Symposium on Student Centered Learning," Teaching and Learning in Medicine, vol. 22 no. 2, 2010, pp. 131-136.

[5] P. James Gee, Introduction to Discourse Analysis; Theory and Method. London : Routledge, 2001.

[6] M. Jorgensen and L. Phillips.Jorgensen, Marianne and Discouse Analysis; as Theory and Method. London : Sage, 2002.

[7] B. Rymes, Classrom Discourse Analysis: A tool for Critical Reflection. New Jesey : Hampton, 2008.

[8] R.Wodak and M. Meyer,Methods of Critical Analysis. London : Sage, 2001.

[9] R. Rogers, An Introduction to Critical Discourse Analysis in education. New York: Routledge. New York : Routledge, 2011.

[10] N. Fairclough, Discourse and social change. Cambridge: Blackwell, 2006.

[11] M. Nasroen, Dasar Falsafah Minagkabau. Jakarta : Penerbit Pasaman, 1957.

[12] E. Piliang and N. Sungut, Tambo Minangkabau. Budaya dan hukum Adat di Minangkabau. Bukittinggi : Kristal Multimedia, 2013.

[13] Manggis, M Rasyid.Minangkabau Sejarah Ringkas dan Adatnya. Jakarta : Mutiara Sumber Widya, 1987.

[14] R. Harman, "Literary intertextuality in genre-based pedagogies: Building lexical cohesion in fifth-grade L2 writing."Journal of Second Language Writing, vol.22 no.2, 2013, pp. 125-140, doi: 1060374313000222 .

[15] D. Latham, "Empowering Adolescent Readers: Intertextuality," Children's Literature in Education, vol.39 no.3, 2008, pp. 213-226, doi: 10.1007/s10583-007-9052-6.

[16] B.Gasparov,Speech, Memory, and Meaning Intertextuality in Everyday Language. Berlin : De Gruyter, 2010.

[17] P. Baker and E. Sibonile.Key terms in Discourse Analysis. New York: Continuиm. New York : Continuum, 2011.

[18] M. Warren, "Just spoke to ....": The types and directionality of intertextuality in professional discourse,"The types and directionality of intertextuality in English for Specific Purposes, vol 32, 2013, pp. 1124.

[19] J. Manak, "The Social Construction of Intertextuality and Literary Understanding: The Impact of Interactive Read-Alouds on the Writing of Third Graders During Writing Workshop,"Reading Research Quarterly, vol. 46 no. 4, 2011, pp. 309-311 doi: 10.1002/RRQ.001.

[20] M. A. Hogg and R.S.Tindale, Blackwell Handbook of Social Psychology: Group Processes. . Oxford : Blackwell, 2001.

[21] R. Vollmeyer and F. Rheinberg, "Motivational Effects on SelfRegulated Learning with Different Tasks,"Educ Psychol Rev, 2006, pp. $239-253$.

[22] Z. Dornyei, The Psychology of the Language learner. Individual Differences in Second Language Acquisition. New Jersey: Lawrence Erlbaum Associates, 2015.

[23] R.Widawsky, "Julia Kristeva Psychoanalytic Work,"Journal of the American Psychoanalytic Association, 2014, pp. 62-67.
[24] V. Samuda and M. Bygate, Task in Second Language Learning. Great Britain: Palgrave Macmillan, 2008.

[25] A. Jordan, O. Carlile, and A. Stack, "Approaches to learning; A Guide for Teachers," New York: The McGrawHill Company, 2008.

[26] P. Mayo, Peter.Hegemony and Education under Neoliberalism Insights from Gramsci. New York : Routledge, 2015.

[27] J. Perumal, "Student resistance and teacher authority: the demands and dynamics of collaborative learning," Journal of Curriculum Studies, vol 40 no. 2, 2008, pp. 381-398, doi: 10.1080_00220270701724570.

[28] Y. Stavrakakis, "Discourse Theory, Post-Hegemonic Critique and Chantal Mouffe's Politics of the Passions," parallax, vol.20 no.2, 2014, pp. 118-135, doi: 10.1080/13534645.2014.896557.

[29] J. Ruiz Ruiz. "Sosiological Discourse Analysis: Methods and Logic." Forum Qualitative Social Research, [Online] May 26, volume 10.no.2 Art.26.May 2009. [Cited: December 25, 2014.] http.www.qualitative .

[30] J. W. Creswell, Educational research: Planning, Conducting, and Evaluating Quantitative and Qualitative research. Boston: Pearson Education, 2012.

[31] P. Mayring, Quantitative Content Analysis. Theoritical Foundation: Basic Procedures and Software Solution. [Online] 2014. [Cited: April 4, 2016.] http://nbn-resulving.de/.

[32] G. Macleod, "Authority and the Teacher,"British Journal of Educational Studies, 2016, pp. 126-129.

[33] J. Jou and J. Foreman, "Transfer of learning in avoiding false memory: The roles of warning, immediate feedback, and incentive," The Quarterly Journal of Experimental Psychology, vol.60 no.6, 2007, pp. 877-896, doi: 10.1080/17470210600831184.

[34] M. Clariana, A. Castelló, and R. Cladellas, "Feeling of knowing and over-claiming in students from secondary school to university,"Learning and Individual Differences, 2010, vol 60. no. 4 2016, pp. 405-417, doi: 10.1111/j.1741-5446.2010.00367.x.

[35] D. Kwak, "Teaching to Unlearn Community in Order to Make a Claim to Community,"2010, Educational Theory, vol 60. no. 4, 2010, pp. 405 417, doi: 10.1111/j.1741-5446.2010.00367.x.

[36] E. Miron-Spektor, D. Efrat-Treister, and A. Raf, "Others' Anger Makes People Work Harder Not Smarter: The Effect of Observing Anger and Sarcasm on Creative and Analytic Thinking,"Journal of Applied Psychology, 2011, pp. 1065-1075.

[37] M.S.Amir, Adat Minagkabau; Pola dan Tujuan Hidup Orang Minang. Jakarta : Citra Harta Prima, 2011.

[38] K. Salmi-Niklander, "Bitter Memories and Burst Soap Bubbles: Irony, Parody, and Satire in the Oral-Literary Tradition of Finnish Working Class Youth at the Beginning of the Twentieth Century," IRSH vol. 52, 2007, pp. 189-207, doi: 10.1017/S0020859007003197.

[39] E. Hirst, "Diverse Voices in a Second Language Classroom: Burlesque, Parody and Mimicry,"Language and Education, vol 17. no. 3, 2014, pp.174-191 doi: 10.1080/09500780308666847.

[40] M. Gagne, The Oxford handbook of Work Engagement, Motivaton, and Self-Determination Theory. Oxford: Oxford University Press, 2014. 